\title{
Evaluation of Dryland Wheat Cultivars on the Market in South Africa for Resistance against Four Known Russian Wheat Aphid, Diuraphis noxia, Biotypes in South Africa
}

\author{
Astrid Jankielsohn \\ ARC-Small Grains, Bethlehem, South Africa \\ Email: jankielsohna@arc.agric.za
}

How to cite this paper: Jankielsohn, A. (2019) Evaluation of Dryland Wheat Cultivars on the Market in South Africa for Resistance against Four Known Russian Wheat Aphid, Diuraphis noxia, Biotypes in South Africa. Advances in Entomology, 7, 1-9.

https://doi.org/10.4236/ae.2019.71001

Received: August 20, 2018

Accepted: December 14, 2018

Published: December 17, 2018

Copyright $\odot 2019$ by author and Scientific Research Publishing Inc. This work is licensed under the Creative Commons Attribution International License (CC BY 4.0). http://creativecommons.org/licenses/by/4.0/

\section{Open Access}

\begin{abstract}
An increased wheat yield potential under changing environmental conditions is a challenge in agriculture. Resistant wheat lines can yield more than susceptible wheat lines in the presence of Russian wheat aphid infestation. There are currently four Russian wheat aphid (RWA) biotypes known in South Africa with different virulence against different wheat cultivars. To keep up with the ever-changing patterns it is necessary to screen the cultivars for resistance against these Russian wheat aphid (RWA) biotypes. All the dryland wheat cultivars on the market were evaluated for resistance against the four known Russian wheat aphid (RWA) biotypes in South Africa. Through this evaluation, the status of Russian wheat aphid (RWA) resistance in South African dryland wheat cultivars can be updated to adapt to environmental changes and the wheat industry can adapt to changes in virulence of Russian wheat aphid (RWA) biotypes that may cause damage to Russian wheat aphid (RWA) resistant cultivars, subsequently affecting yield. Evaluations were done in the glasshouse by screening wheat cultivars against four different South African Russian wheat aphid (RWA) biotypes, RWASA1-RWASA4, under controlled conditions. The glasshouse evaluations showed that out of the 19 dryland wheat cultivars currently on the market in South Africa 16 are resistant against RWASA1, 7 are resistant against RWASA2, 7 are resistant against RWASA3 and 5 are resistant against RWASA4. Dryland wheat cultivars were also evaluated under field conditions at four different field localities. In the field, 5 cultivars were resistant to RWASA3 at two localities, respectively, and 3 and 5 cultivars were resistant to RWASA 4 at two localities, respectively. Since Russian wheat aphid (RWA) damage can influence the final yield of a wheat cultivar significantly, changing conditions can influence
\end{abstract}


both resistant cultivars, and the virulence of Russian wheat aphid (RWA). It is advisable to evaluate wheat cultivars on the market under different conditions and with all known Russian wheat aphid (RWA) biotypes in an area.

\section{Keywords}

Wheat Cultivars, Russian Wheat Aphid, Resistance

\section{Introduction}

Wheat yield is one of the most important factors to consider by wheat producers and increased yield under changing conditions is a priority in wheat breeding. Biotic factors can influence the final yield significantly and managing the ecology, distribution, virulence patterns, and variability of pests and diseases may minimize the gap between actual and attainable yields. The Russian wheat aphid (RWA), Diuraphis noxia, is a serious pest to small grain production throughout the world. The economic impact from this pest can be considerable and has been estimated at \$893 million for 1987-1993 in the Western United States [1]. The Russian wheat aphid has also caused substantial yield losses of dryland wheat in the summer rainfall areas of South Africa [2]. Although RWA is widely distributed, the economic impact to small grains occurs predominantly in South Africa, the US and Canada [3]. Calhoun et al. [4] found that expression of RWA foliar symptom scores (chlorosis and leaf rolling) in barley is a good indicator of yield reduction because of RWA feeding. Genotypes with low RWA score (resistant) were higher yielding. It is suggested that the most important contributing factor to yield reduction in small grains attacked by RWA is head trapping, resulting from the aphid's prevention of the unrolling of newly emerging leaves [5] [6]. Lal Hussain Akhtar et al. [7] found that Russian wheat aphid infestation caused a significant loss to grain yield in wheat and according to Karren [8], each $1 \%$ infestation level of RWA will result in $0.5 \%$ yield loss of wheat at harvest. Mornhinweg et al. [9] found that the effect of RWA feeding on grain yield and yield components varied with RWA resistance, where resistant lines showed increased grain yield. Randolph et al. [10] concluded that resistant wheat lines could yield more than susceptible wheat lines in the presence of Russian wheat aphid. Current management practices for winter wheat include the use of resistant cultivars, and it is important to ensure that cultivars released in South Africa have sufficient, but more importantly, lasting resistance against the Russian wheat aphid in order to minimize yield losses as far as possible. Russian wheat aphid changes and adapts to changing environments resulting in biotypes with different virulence patterns and cultivars need to be adapted to these changing patterns. There are currently four Russian wheat aphid biotypes known in South Africa [11]. These biotypes differ in their virulence against different wheat cultivars with different resistance genes in South Africa. RWASA1 is the first biotype 
that was recorded in 1978 [12]. RWASA2, relatively unaffected by the Dn1 resistant gene in wheat, was reported in 2005 [13]. RWASA3, relatively unaffected by the Dn4 resistant gene in wheat, was reported in 2009 [14]. During 2011, RWASA4, relatively unaffected by the Dn5 resistant gene, was reported [15]. Increased genetic diversity in wheat breeding is an effective tool for dealing with present and future challenges caused by the need for increased yields, by climate change and adaptation of pest insects. The evaluation of wheat cultivars on the market in South Africa for resistance against different Russian wheat aphid biotypes ensures that the status of RWA resistance in South African wheat cultivars is continually updated as the environment and the RWA biotype status changes. This enables the wheat industry to adapt to changes in virulence of RWA biotypes that may cause damage to RWA resistant cultivars, subsequently affecting yield.

\section{Material and Methods}

\subsection{Glasshouse Screening}

There are currently 19 dryland wheat cultivars on the market in South Africa. These cultivars were screened against four RWA biotypes (RWASA1 - RWASA4) in the glasshouse using the bioassay developed by Du Toit [16]. Ten seeds of each cultivar were planted in a seedling tray filled with sterilized sand in a randomized complete block design with four replications for each cultivar and biotype combination. Cultivar entries were randomly assigned to rows and were separated by border rows planted with RWA susceptible Tugela. Plants were kept in glasshouse cubicles at night/day temperatures of $16^{\circ} \mathrm{C} / 22^{\circ} \mathrm{C}$, natural light. Immediately after planting, the seedling trays were placed in gauze (315 micron) cages to avoid contamination by secondary aphids. Plants were infested at the two-leaf stage with RWA biotype clone colonies. Biotypes used in screenings are clones of field collected RWA samples that are cultured in the glasshouse at ARC-Small Grain. Plants were rated with a ten-point damage rating scale, which included leaf chlorosis and leaf rolling [17]: 1, no damage; 2, minor chlorosis; 3 , average chlorosis; 4 , major chlorosis; 5 , minor streaking; 6, major streaking; 7, minor rolling; 8, average rolling; 9, major rolling; and 10, death of plant. Chlorosis varied from a few chlorotic spots on the leave (minor) to the whole leaf being covered with chlorotic spots (major), while streaking varied from a few streaks on the leaf (minor) to streaking on the whole length of the leaf (major). The mean rating for ten plants allocated scores of 1, 2, $3=$ highly resistant; 4, 5, $6=$ moderately resistant; 7, 8, $9=$ susceptible and $10=$ dead. The mean damage rating was then calculated. A general damage assessment was given and the following abbreviations used $\mathrm{HR}=$ highly resistant; $\mathrm{R}=$ resistant; $\mathrm{MR}=$ moderately resistant and $\mathrm{S}=$ susceptible.

\subsection{Field Screening}

To avoid the bias that may be associated with screening under artificial condi- 
tions the 19 dryland wheat cultivars on the market in South Africa were evaluated in the field. The cultivars were planted on 29/06/2017 in $5 \mathrm{~m} \times 5$ row plots at 4 different localities in the Free State. All of these localities lies in the summer rainfall area of South Africa: Clarens (GPS: S28 ${ }^{\circ} 23.913^{\prime} \mathrm{E} 28^{\circ} 25.760^{\prime}$; average annual rainfall $-764 \mathrm{~mm}$; average annual temperature $-13.7^{\circ} \mathrm{C}$ ), Clocolan1 (GPS: $\mathrm{S} 28^{\circ} 59^{\prime} 15.51^{\prime \prime E} 27^{\circ} 40^{\prime} 06.52^{\prime \prime}$; average annual rainfall $-635 \mathrm{~mm}$; average annual temperature-14.9 $9^{\circ}$, Clocolan2 (GPS: S29 $00^{\prime} 03.98^{\prime \prime E} 27^{\circ} 38^{\prime} 12.91^{\prime \prime}$; average annual rainfall-635 $\mathrm{mm}$; average annual temperature-14.9 ${ }^{\circ}$ ) and Ficksburg (GPS: S28 $47.556^{\prime} \mathrm{E} 27^{\circ} 57.917^{\prime}$; average annual rainfall $-621 \mathrm{~mm}$; average annual temperature $\left.-15.1^{\circ} \mathrm{C}\right)$. The trial layout was a randomized complete block design with four replications. Data were collected from the middle rows to avoid border effects. The cultivars were evaluated in the field on 30/10/2017 at adult stage on a 1 - 4-point scale where 1-no damage: Escape/Resistant (R); 2-chloretic spots on leaves: Resistant (R); 3-longitudinal striping on leaves: Medium susceptible (S); 4-rolling of leaves: susceptible (S).

RWA samples were collected at each locality and the biotype for the locality was determined. A single female aphid from each sample collected in the field was transferred to a wheat plant and caged (gauze size: 315 micron) to produce a clone colony. The biotype of each RWA clone was determined by screening its feeding damage on 11 previously established plant resistant sources containing designated resistance genes $D n 1$ to $D n 9$ and $D n x$ and $D n y$ (Table 1). Ten seeds of each plant entry were planted in a seedling tray filled with sterilized sand in a randomized complete block design with four replications for each biotype determination. Plant entries were randomly assigned to rows and were separated by border rows planted with RWA susceptible Tugela. Plants were kept in glasshouse cubicles at night/day temperatures of $16^{\circ} \mathrm{C} / 22^{\circ} \mathrm{C}$, natural light. Immediately after planting, the seedling trays were placed in gauze ( 315 micron) cages to avoid contamination by secondary aphids. Plants were infested at the two-leaf stage with RWA clone colonies of collected samples. Plants were rated with a ten-point damage rating scale, which included leaf chlorosis and leaf rolling. A score from 1 - 4 describes leaf chlorosis, 5 - 6 striping on the leaves and 7 10 rolling. Once the susceptible wheat Tugela showed susceptible damage symptoms, all plants were rated. RWA biotypes were classified by using damage ratings for each plant entry where the plant was considered resistant (R) if the damage rating was $1-6.5$ and susceptible (S) if the damage rating was $6.5-10$. Each clone was given a biotype designation based on the differential virulence profile to the $D n 1$ to $D n 9$ resistance genes. Infestations of RWASA1 cause susceptible damage symptoms on wheat entries containing the $D n 2$ and $D n 3$ gene (Table 1). RWASA2 cause susceptible damage symptoms on wheat entries containing $D n 1, D n 2, D n 3, D n 8$ and $D n 9$ resistance genes (Table 1). RWASA3 is distinguished from RWASA2 by its added virulence to Dn4 and RWASA4 is distinguished from RWASA3 by its added virulence to Dn5 (Table 1).

Russian wheat aphid damage rating across all cultivars were analysed using a two-way (damage rating, cultivar) analysis of variance (ANOVA). Mean damage 
Table 1. RWA resistant sources against four South African RWA biotypes.

\begin{tabular}{cccccc}
\hline & & \multicolumn{3}{c}{ South African Biotypes } \\
\hline Wheat genotype & Resistance gene & RWASA1 & RWASA2 & RWASA3 & RWASA4 \\
\hline C003797 & Dn1 & $\mathrm{R}$ & $\mathrm{S}$ & $\mathrm{S}$ & $\mathrm{S}$ \\
C003804 & Dn2 & $\mathrm{S}$ & $\mathrm{S}$ & $\mathrm{S}$ & $\mathrm{S}$ \\
C003811 & Dn3 & $\mathrm{S}$ & $\mathrm{S}$ & $\mathrm{S}$ & $\mathrm{S}$ \\
Yumar & Dn4 & $\mathrm{R}$ & $\mathrm{R}$ & $\mathrm{S}$ & $\mathrm{S}$ \\
C09500043 & Dn5 & $\mathrm{R}$ & $\mathrm{R}$ & $\mathrm{R}$ & $\mathrm{S}$ \\
C0960223 & Dn6 & $\mathrm{R}$ & $\mathrm{R}$ & $\mathrm{R}$ & $\mathrm{R}$ \\
$94 \mathrm{M} 370$ & Dn7 & $\mathrm{R}$ & $\mathrm{R}$ & $\mathrm{R}$ & $\mathrm{R}$ \\
Karee- $D n 8$ & Dn8 & $\mathrm{R}$ & $\mathrm{S}$ & $\mathrm{S}$ & $\mathrm{S}$ \\
Betta- $D n 9$ & Dn9 & $\mathrm{R}$ & $\mathrm{S}$ & $\mathrm{S}$ & $\mathrm{S}$ \\
PI586955 & Dnx & $\mathrm{R}$ & $\mathrm{R}$ & $\mathrm{R}$ & $\mathrm{R}$ \\
Stanton & Dny & $\mathrm{R}$ & $\mathrm{R}$ & $\mathrm{S}$ & $\mathrm{S}$ \\
\hline
\end{tabular}

$\mathrm{R}=$ RWA resistant; $\mathrm{S}=$ RWA susceptible.

rate entries with significant $(\mathrm{P}<0.05)$ clone-by-plant interactions were separated by Fisher's protected least significant difference (LSD) test at the $5 \%$ level.

\section{Results and Discussion}

\subsection{Glasshouse Screening}

RWASA4 is the most virulent South African biotype and of the known genotypes only the ones containing the $D n 6, D n 7$ and $D n x$ genes have adequate resistance against this biotype ([11], Table 1). Genotypes containing resistant genes $D n 1, D n 4-D n 9$ and $D n x$ and Dny are resistant against RWASA1, genotypes containing $D n 4-D n 7, D n x$ and $D n y$ are resistant against RWASA2 and those containing $D n 5-D n 7$ and $D n x$ are resistant against RWASA3 (Table 1). These genes used singly or in combination can be used to confer resistance to wheat cultivars.

RWA biotypes with different virulence patterns against current wheat cultivars on the market occur in different wheat production areas in South Africa. It is therefore important to determine the virulence of the different biotypes against cultivars on the market in order to make recommendations as to which cultivar has resistance to a biotype occurring in a specific area. Glasshouse screening of the dryland cultivars in South Africa showed that the wheat cultivars have different resistant and susceptible reactions to the four different biotypes (Table 2). The glasshouse evaluations showed that out of the 19 dryland wheat cultivars currently on the market in South Africa 16 are resistant (RWA damage score $<6.5$ ) against RWASA1, 7 are resistant against RWASA2, 7 are resistant against RWASA3 and 5 are resistant against RWASA4 (Table 2).

Evaluation under controlled conditions in the glasshouse gives us a guideline of resistance of wheat cultivars against the four different RWA biotypes. 
Table 2. RWA mean damage ratings for dryland wheat cultivars on the market in South Africa (Glasshouse screening against four RWA biotypes).

\begin{tabular}{ccccc}
\hline & RWASA1 & RWASA2 & RWASA3 & RWASA4 \\
\hline ELANDS & $4.33 \mathrm{bc}$ & $8.76 \mathrm{a}$ & $7.43 \mathrm{bcd}$ & $8.33 \mathrm{a}$ \\
GARIEP & $4.38 \mathrm{bc}$ & $8.71 \mathrm{a}$ & $7.72 \mathrm{abc}$ & $8.33 \mathrm{a}$ \\
KOONAP & $4.00 \mathrm{cdef}$ & $9.00 \mathrm{a}$ & $7.81 \mathrm{abc}$ & $7.71 \mathrm{abc}$ \\
MATLABAS & $4.00 \mathrm{cdef}$ & $8.10 \mathrm{ab}$ & $7.09 \mathrm{~cd}$ & $7.81 \mathrm{ab}$ \\
SENQU & $4.19 \mathrm{cde}$ & $9.00 \mathrm{a}$ & $6.95 \mathrm{cde}$ & $8.05 \mathrm{ab}$ \\
PAN3111 & $8.76 \mathrm{a}$ & $8.90 \mathrm{a}$ & $8.667 \mathrm{ab}$ & $8.71 \mathrm{a}$ \\
PAN3118 & $8.95 \mathrm{a}$ & $8.67 \mathrm{ab}$ & $9.00 \mathrm{a}$ & $9.00 \mathrm{a}$ \\
PAN3120 & $8.86 \mathrm{a}$ & $8.86 \mathrm{a}$ & $9.00 \mathrm{a}$ & $9.00 \mathrm{a}$ \\
PAN3161 & $3.33 \mathrm{ef}$ & $4.14 \mathrm{e}$ & $4.05 \mathrm{hi}$ & $5.95 \mathrm{bcdef}$ \\
PAN3195 & $4.093 \mathrm{cde}$ & $9.00 \mathrm{a}$ & $4.14 \mathrm{hi}$ & $5.29 \mathrm{ef}$ \\
PAN3198 & $4.00 \mathrm{cdef}$ & $7.67 \mathrm{abc}$ & $7.28 \mathrm{bcd}$ & $7.00 \mathrm{abcde}$ \\
PAN3368 & $4.47 \mathrm{cde}$ & $4.00 \mathrm{e}$ & $4.43 \mathrm{ghi}$ & $4.8 \mathrm{f}$ \\
PAN3379 & $3.43 \mathrm{def}$ & $4.29 \mathrm{e}$ & $4.00 \mathrm{hi}$ & $4.00 \mathrm{f}$ \\
SST316 & $3.95 \mathrm{cdef}$ & $6.19 \mathrm{~d}$ & $6.86 \mathrm{cde}$ & $8.29 \mathrm{a}$ \\
SST317 & $4.33 \mathrm{bc}$ & $6.34 \mathrm{~cd}$ & $6.10 \mathrm{def}$ & $7.81 \mathrm{ab}$ \\
SST347 & $4.14 \mathrm{cde}$ & $6.09 \mathrm{~d}$ & $4.81 \mathrm{fghi}$ & $7.00 \mathrm{abcde}$ \\
SST356 & $5.14 \mathrm{~b}$ & $8.81 \mathrm{a}$ & $7.19 \mathrm{~cd}$ & $7.48 \mathrm{abcd}$ \\
SST374 & $3.14 \mathrm{f}$ & $4.52 \mathrm{e}$ & $3.52 \mathrm{i}$ & $5.52 \mathrm{def}$ \\
SST387 & $3.67 \mathrm{cdef}$ & $7.29 \mathrm{bcd}$ & $7.43 \mathrm{bcd}$ & $7.05 \mathrm{abcde}$ \\
LSD (5\% level) & 0.8660 & 1.397 & 1.444 & 2.141 \\
\hline
\end{tabular}

Means within a column followed by the same lowercase letter are not significantly different $(\mathrm{P}>0.0001)$.

\subsection{Field Screening}

During 2017 there was a high natural infestation of Russian wheat aphid at the trial sites at Clarens, Clocolan and Ficksburg. This resulted in noticeable damage symptoms on both RWA susceptible and resistant cultivars. Screening of RWA samples collected at the field localities showed that the dominant RWA biotype at Clocolan1 and Clocolan2 was RWASA3 and at Clarens and Ficksburg was RWASA4. In the field at Clocolan1 5 cultivars were resistant (RWA damage score $<3$ ) to RWASA3; at Clocolan2 5 cultivars were resistant to RWASA3; at Ficksburg 3 cultivars were resistant to RWASA4 and at Clarens 5 cultivars were resistant to RWASA4. The cultivars in the field showed a different susceptible/resistant reaction compared to the cultivars screened in the. In the field SST387 showed resistance against RWASA3 and RWASA4 (Table 3), while this cultivar showed only resistance against RWASA1 in the glasshouse (Table 2). When looking at resistance of wheat cultivars against RWA it must be kept in mind that, there are various factors in the field that will influence the interaction between RWA and its host plant. This includes environmental conditions such 
Table 3. Evaluation of RWA resistance of dryland wheat cultivars in the field at different localities.

\begin{tabular}{ccccc}
\hline Locality & Clocolan1 & Clocolan2 & Ficksburg & Clarens \\
\hline Biotype & RWASA3 & RWASA3 & RWASA4 & RWASA4 \\
\hline ELANDS & $3.25 \mathrm{ab}$ & $3.25 \mathrm{ab}$ & $3.25 \mathrm{ab}$ & $4.00 \mathrm{a}$ \\
GARIEP & $3.25 \mathrm{ab}$ & $3.50 \mathrm{a}$ & $3.50 \mathrm{a}$ & $3.50 \mathrm{a}$ \\
KOONAP & $3.25 \mathrm{ab}$ & $3.75 \mathrm{a}$ & $3.75 \mathrm{a}$ & $3.00 \mathrm{a}$ \\
MATLABAS & $3.25 \mathrm{ab}$ & $3.75 \mathrm{a}$ & $3.75 \mathrm{a}$ & $3.25 \mathrm{a}$ \\
SENQU & $3.50 \mathrm{ab}$ & $3.00 \mathrm{ab}$ & $3.00 \mathrm{ab}$ & $3.50 \mathrm{a}$ \\
PAN3111 & $3.50 \mathrm{ab}$ & $3.00 \mathrm{ab}$ & $3.00 \mathrm{ab}$ & $3.50 \mathrm{a}$ \\
PAN3118 & $3.25 \mathrm{ab}$ & $3.75 \mathrm{a}$ & $3.25 \mathrm{ab}$ & $3.25 \mathrm{a}$ \\
PAN3120 & $3.50 \mathrm{ab}$ & $3.75 \mathrm{a}$ & $3.75 \mathrm{ab}$ & $3.50 \mathrm{a}$ \\
PAN3161 & $3.50 \mathrm{ab}$ & $3.25 \mathrm{ab}$ & $3.25 \mathrm{ab}$ & $2.75 \mathrm{ab}$ \\
PAN3195 & $3.75 \mathrm{a}$ & $3.25 \mathrm{ab}$ & $3.25 \mathrm{ab}$ & $2.50 \mathrm{~b}$ \\
PAN3198 & $3.50 \mathrm{ab}$ & $3.00 \mathrm{ab}$ & $3.00 \mathrm{ab}$ & $2.50 \mathrm{~b}$ \\
PAN3368 & $2.00 \mathrm{~b}$ & $2.75 \mathrm{ab}$ & $3.75 \mathrm{a}$ & $2.50 \mathrm{~b}$ \\
PAN3379 & $2.00 \mathrm{~b}$ & $2.75 \mathrm{ab}$ & $2.75 \mathrm{ab}$ & $3.50 \mathrm{a}$ \\
SST316 & $3.25 \mathrm{ab}$ & $3.25 \mathrm{ab}$ & $3.25 \mathrm{ab}$ & $3.50 \mathrm{a}$ \\
SST317 & $3.00 \mathrm{ab}$ & $3.25 \mathrm{ab}$ & $3.25 \mathrm{ab}$ & $3.25 \mathrm{a}$ \\
SST347 & $2.25 \mathrm{ab}$ & $2.75 \mathrm{ab}$ & $3.50 \mathrm{a}$ & $3.25 \mathrm{a}$ \\
SST356 & $3.5 \mathrm{ab}$ & $3.00 \mathrm{ab}$ & $3.00 \mathrm{ab}$ & $4.00 \mathrm{a}$ \\
SST374 & $2.25 \mathrm{ab}$ & $2.75 \mathrm{ab}$ & $2.00 \mathrm{~b}$ & $3.00 \mathrm{a}$ \\
SST387 & $2.25 \mathrm{ab}$ & $2.75 \mathrm{ab}$ & $2.75 \mathrm{ab}$ & $2.75 \mathrm{ab}$ \\
LSD $5 \%)$ & 1.52 & 1.37 & 1.37 & 1.62 \\
\hline & & & & \\
\hline
\end{tabular}

Means within a column followed by the same lowercase letter are not significantly different $(\mathrm{P}>0.0001)$.

as drought and high temperatures. These environmental conditions can influence the expression of resistance in the plant, while it can also influence the population pressure of the RWA and consequently the damage to the plant. Macedo et al. [18] found that plant growth stages, time and duration of feeding, nutritional status of the host plants, aphid abundance and other environmental factors affect plant responses to RWA feeding. SST387 is a drought resistant cultivar and this characteristic might have given this cultivar an advantage to withstand RWA damage under drought conditions. The conditions of screening for RWA resistance under artificial conditions in the glasshouse is much more rigorous than under natural conditions occurring in the field. Seedlings are infested at an early stage with a larger number of aphids compared to what normally occurs in the field and aphids protected in the glasshouse from exposure to natural enemies common in the field, as well as wind and rain can increase populations rapidly, even on open leaves. On the other hand, seedlings in the glasshouse have enough moisture, nutrients and favourable temperatures and 
are not exposed to natural stresses in the field, which could influence the expression of resistance. Smith, et al. [19] found that changes in lighting, temperature, relative humidity, and soil nutrient conditions commonly affect the expression of insect resistance in crop plants. There may be lines with useful levels of field resistance that might be passed over as susceptible if only glasshouse screening were relied on. Since RWA damage can influence the final yield of a wheat cultivar significantly, and changing conditions can influence both resistant cultivars, and the virulence of RWA, it is desirable to evaluate wheat cultivars on the market under different conditions and with all known RWA biotypes in an area.

\section{Conclusion}

The development of germplasm with adequate and lasting resistance against pests and diseases in wheat is of importance to wheat producers to reach the desired yield with less costly inputs. To achieve this objective it is necessary to screen existing wheat cultivars to ensure that these cultivars have adequate resistance against the RWA biotypes prevalent in the areas where these cultivars are planted. Glasshouse screening under controlled conditions is useful to determine levels of resistance, but is not necessarily a reflection of RWA resistance expressed in the field. It is therefore also necessary to do field evaluations in different areas to determine the expression of resistance under different conditions. Natural enemies, temperature, moisture, wind, soil type, host quality are all variables that will have an influence on RWA population growth and as a result pest pressure. The prevalent RWA biotype will also differ in different areas. This is necessary to keep pace with changes in pest virulence resulting from fluctuating environments.

\section{Conflicts of Interest}

The author declares no conflicts of interest regarding the publication of this paper.

\section{References}

[1] Morrison, W.P. and Peairs, F.B. (1998) Response Model Concept and Economic Impact. In: Quisenberry, S.S. and Peairs, F.B., Eds., Response Model for Russian Wheat Aphid, Thomas Say Publications in Entomology, Entomological Society of America, Lanham, MD.

[2] Du Toit, F. and Walters, M.C. (1984) Damage Assessment and Economic Threshold Values for the Chemical Control of the Russian Wheat Aphid, Diuraphisnoxia (Mordvilko) on Winter Wheat. In: Walters, M.C., Ed., Progress in Russian Wheat Aphid (Diuraphisnoxia) Research in the Republic of South Africa, Technical Communication No. 191, Republic of South Africa, Department of Agriculture, 58-62.

[3] Lage, J., Skovmand, B. and Andersen, S.B. (2004) Resistance Categories of Synthetic Hexaploid Wheats Resistant to the Russian Wheat Aphid (Diuraphidsnoxia) Euphytica, 136, 291-196. https://doi.org/10.1023/B:EUPH.0000032732.53350.93

[4] Calhoun, D.S., Burnett, P.A., Robinson, J., Vivar, H.E. and Gilchrist, L. (1991) Field Resistance to Russian Wheat Aphid in Barley: II Yield Assessment. Crop Science, 
31, 1464-1467. https://doi.org/10.2135/cropsci1991.0011183X003100060014x

[5] Burd, J.D. and Burton, R.L. (1992) Characterization of Plant Damage Caused by Russian Wheat Aphid (Homoptera. Aphididae). Journal of Economic Entomology, 85, 2017-2022. https://doi.org/10.1093/jee/85.5.2017

[6] Robinson, J. (1994) Identification and Characterization of Resistance to Russian Wheat Aphid in Small Grain Cereals: Investigations at CIMMYT, 1990-92. CIMMYT Research Report No. 3. CIMMYT, Mexico, D.F.

[7] Akhtar, L.H., Hussian, M., Muhammad Iqbal, R., Amer, M. and Hussain Tariq, A. (2010) Losses in Grain Yield Caused by Russian Wheat Aphid Diuraphisnoxia (Mordvilko). Sarhad Journal of Agriculture, 26, 625-628.

[8] Karren, J.B. (1989) Russain Wheat Aphid in Uta. Utah State University, Extension Entomology, Department of Biology, UT 84322-5349. https://digitalcommons.usu.edu/extension_histall/755

[9] Mornhinweg, D.W., Brewer, M.J. and Porter, D.R. (2006) Effect of Russian Wheat Aphid on Yield and Yield Components of Field Grown Susceptible and Resistant Spring Barley. Crop Science, 46, 36-42. https://doi.org/10.2135/cropsci2004.0768

[10] Randolph, T.L., Peairs, F.B., Koch, M.K., Walker, C.B. and Quick, J.S. (2005) Influence of Three Resistance Sources in Winter Wheat Derived from TAM 107 on Yield Response to Russian Wheat Aphid. Journal of Economic Entomology, 98, 389-394. https://doi.org/10.1093/jee/98.2.389

[11] Jankielsohn, A. (2017) Influence of Environmental Fluctuation on the Russian Wheat Aphid Biotype Distribution in South Africa. Acta Scientific Agriculture, 1.3, 01-06.

[12] Walters, M.C., Penn, F., Du Toit, F., Botha, T.C., Aalbersberg, K., Hewitt, P.H. and Broodryk, W. (1980) The Russian Wheat Aphid. Fmg S. Afr. Leaflet Series Wheat G3, 1-6.

[13] Tolmay, V.L., Lindeque, R.C. and Prinsloo, G.J. (2007) Preliminary Evidence of a Resistance-Breaking Biotype of the Russian Wheat Aphid, Diuraphis noxia (Kurdjumov) (Homoptera: Aphididae), in South Africa. African Entomology, 15, 228-230. https://doi.org/10.4001/1021-3589-15.1.228

[14] Jankielsohn, A. (2011) Distribution and Diversity of Russian Wheat Aphid (Hemiptera: Aphididae) Biotypes in South Africa and Lesotho. Journal of Economic Entomology, 104, 1736-1741. https://doi.org/10.1603/EC11061

[15] Jankielsohn A (2014) The Russian Wheat Aphid. Farmer's Weekly, 17 January 2014, 22-23.

[16] Du Toit, F. (1988) A Greenhouse Test for Screening Wheat Seedlings for Resistance to the Russian Wheat Aphid Diuraphisnoxia (Homoptera: Aphididae). Phytophylactica, 20, 321-322.

[17] Tolmay, V.L. (1995) The Inheritance and Mechanisms of Russian Wheat Aphid (Diuraphisnoxia) Resistance in Two Triticumaestivum Lines. M.Sc. Thesis, University of the Orange Free State, Bloemfontein.

[18] Macedo, T.B., Hiflwy, L.G., Ni, X. and Quisenberry, S.S. (2003) Light Activation of Russian Wheat Aphid-Elicited Physiological Responses to Susceptible Wheat. Journal of Economic Entomology, 96, 194-201. https://doi.org/10.1093/jee/96.1.194

[19] Smith, C.M., Khan, Z.R. and Pathak, M.D. (1994) Techniques for Evaluating Insect Resistance in Crop Plants. CRC Press, Inc., Florida. 